\title{
Architect Johann August Giesel (1751-1822) and the Question of the "English Garden" in Saxony
}

\author{
Vincent Dupanier ${ }^{1, *}$
}

${ }^{1}$ Université Paris Nanterre, Nanterre, France

*Corresponding author. Email: vincent.dupanier@gmail.com

\begin{abstract}
The place of the architect Johann August Giesel (1751-1822) in the contribution to the picturesque or English Garden in Saxony is not to be overlooked. The pupil of the painter Charles-François Huttin and the architect Friedrich August Krubsacius, he worked on the reconstruction sites of Dresden after the destruction of the Seven Years' War. But it was in France where he got to learn innovative ideas in the garden art. Called in France by Prince Xavier of Saxony, former regent of the Duchy of Saxony, he learned from great architects like Jean-François-Thérèse Chalgrin. Returning to Saxony in 1782, he became one of the creators of the first picturesque garden and follies in Dresden.
\end{abstract}

\section{Keywords: garden, architecture, XVIII century, France, Germany, Saxony, Champagne}

\section{INTRODUCTION}

In 1788, Heinrich Keller noted that the first "English-style" garden in Saxony happened to be the work of the architect, Johann August Giesel, in the garden of the palace der Sekundogenitur in Dresden ("Fig. 1"). How can we situate the introduction of the "English-style" in Saxony? Where did the inspirations come from in his career as an architect?

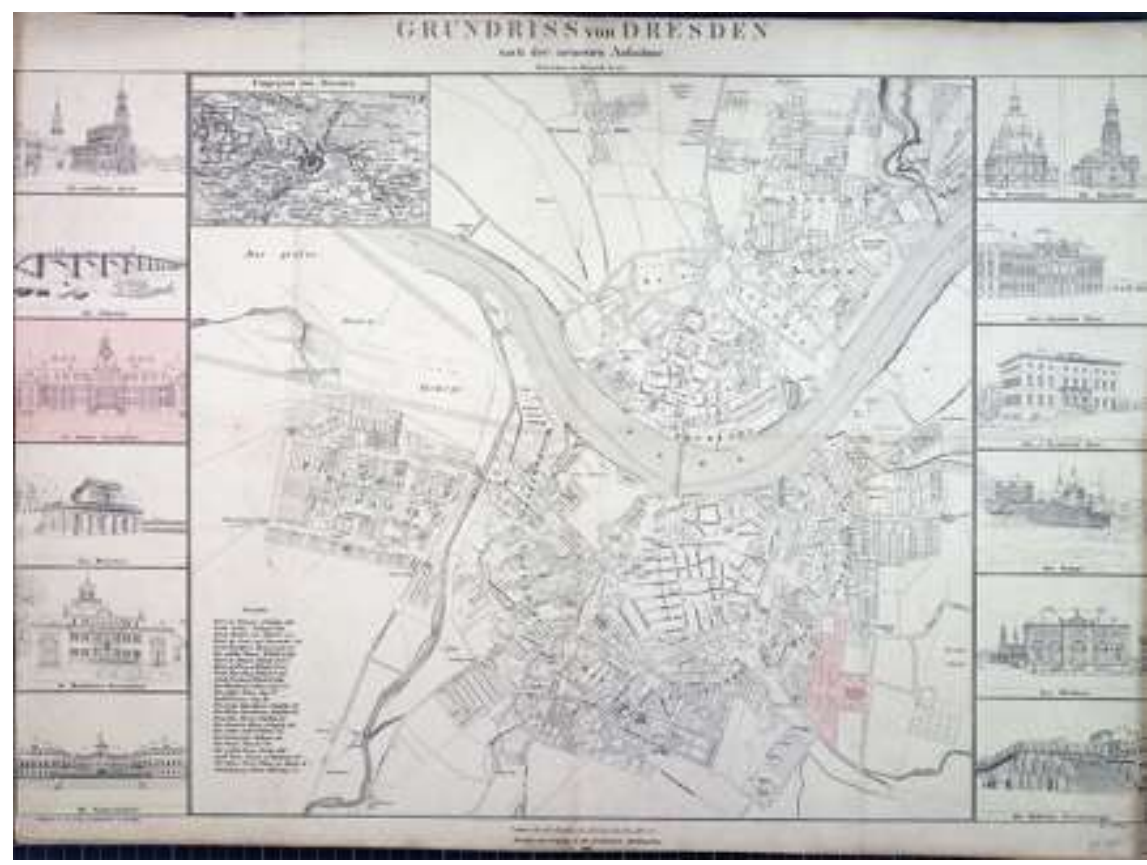

Fig. 1. The Map of Dresden, engraving, 1828 @ Deutsche Fotothek / Lesch, Heinrich.

\section{BIOGRAPHY OF JOHANN AUgUST GiESEL}

Born in 1751, Johann August Giesel was the son of a construction worker from Dresden. He owes him his first steps in learning his trade through solid technical training. His older brother Johann Ludwig Giesel, born in 1747, a painter who carried out his apprenticeship at the academy with Charles-François Huttin (1715 1776), the academy's director since 1764 , then in the 
workshop of the painter Johann Eleazar Zeissig also known as Schenau (1737 - 1818). Between 1764 and 1769, Johann August Giesel also entered the studio of Charles-François Huttin, where he learned mathematics and drawing. Then he studied architecture with Charles F. Renner, who was a master of fortifications (Festungsmauermeister).

In 1766, he became a mason during the construction of the palace der Sekundogenitur (Palais der Sekundogenitur) under the orders of the architect Friedrich August Krubsacius (1718 - 1789). He is reported to have managed to enter the corps of engineers of the electoral military administration and worked under Ingenieur-Oberst E. G. Francke.

In 1773, he was called in France by Prince Xavier of Saxony (1730 - 1806). He became "Inspecteur des Bâtiments" at Pont-sur-Seine castle and Paris. Still very much linked to his country of origin, he made many trips to see his family in Dresden and thought to return to Saxony in 1780 . Nevertheless, the prince has done everything to keep him in his service, which showed his satisfaction with the work of the architect. But in 1782, the architect definitively returned to Saxony, where he pursued his career as an architect and construction director (baudirektor) first with Prince Maximilian of Saxony (1759 - 1838). He carried out numerous works in his gardens and palaces, notably in the Prinz-MaxPalace (Prinz-Max-Palais) of Friedrichstäder Alley in Dresden. In 1783, he entered the House of Prince Antoine of Saxony (1755 - 1836), the future king of Saxony, and, under the same title, then became the garden inspector (Garten inspektor). During this time, he has performed many works in the palace der Sekundogenitur known as Prinz-Anton-Palace (PrinzAnton-Palais), which is of particular interest to us.

Historians attribute to Johann August Giesel the realization of the transformations in the palace, in particular, the creation of a picturesque garden with follies including one in the form of an ancient ruin of a Doric temple (Dorischen Tempel Ruine) at an artificial lake ("Fig. 2").

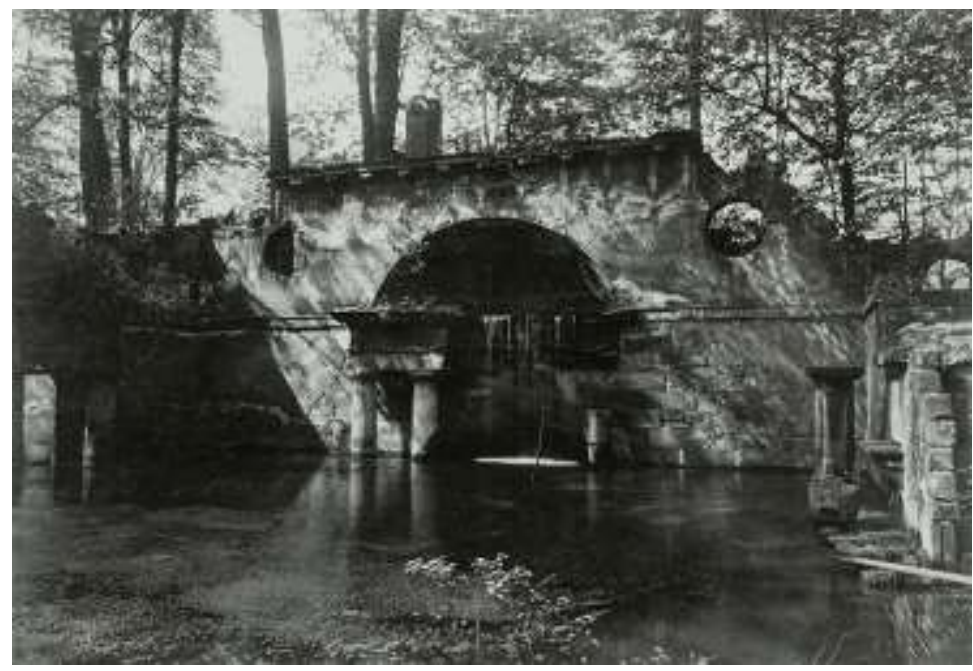

Fig. 2. Palais der Sekundogenitur, Künstliche Ruine, photography, circa 1954, @ SLUB / Deutsche Fotothek / Unknown photographer.

This palace, created for the Georg of Saxony, also called "Chevalier de Saxe" (1704 - 1774), was sold in 1778 by his heiress Friederike Alexandrine Gräfin von Moszinska to Marie-Antoinette of Bavaria, mother of the Elector, who has done a lot of works there. Upon his death, his son Charles of Saxony, brother of the Elector Frédéric-August III, inherited it but did not seem to do any work. Then when the latter died, in 1780, the palace returned to Prince Antoine - his brother. It is the latter who called on then-architect Johann August Giesel. In 1782, the palace garden had numerous pavilions, one of which was in "Chinesestyle" but no signs of the "English" garden. According to Fritz Löffler, the work was carried out from 1783 to 1788. There are no known archives on this subject, but several documents from the XX century make its state understandable before its destruction in the late 1960s. This construction was located at the end of the artificial river to the right of the building ("Fig. 2"). It was comprised of a wall with a large niche where there was a portico surmounted by an entablature, and on the side, another portico surmounted by an entablature and a tympanum. The wall was decorated with two oculi above a cornice, but also with Doric columns and other half-collapsed walls. Finally, this park had both classical and "English-style" gardens. The park has been destroyed during the second war and became the Blüherparks in Dresden afterward.

In 1789, Johann August Giesel still worked in Dresden in the Prinz-Max-Palace, then at the new constructions of the castle Mückenberg (Lauchhammer, Lower Saxony) from 1794 to 1804 . At the time of his 
death in 1822, he was the director and inspector of royal gardens in Dresden (Baudirecteur und Inspektor des königlichen Garten zu Dresden). He was married to Maria Elisabeth, but they did not have children who reached adulthood. Now we must consider what he did in France at Pont-sur-Seine garden during his stay there.

\section{WORKS IN THE GARDEN OF PONT-SUR- SEINE, THE PROPERTY OF XAVIER OF SAXONY}

Prince Xavier of Saxony, also called "Comte de Lusace," was the second son of the King of Poland and the Elector of Saxony Augustus III (1696 - 1763). The lieutenant of the King of France's armies during the Seven Years' War (1756 - 1763), he became, on the death of his older brother in December 1763, the regent of Saxony. During the regency, he has put in place a policy aimed at rehabilitating a ruined duchy and a capital partially destroyed by the Prussian bombings during the war. In 1764, Prince Xavier laid the foundations for the reconstruction of the Protestant Holy-Cross church damaged by the Prussian bombings in 1760. Its reconstruction has become a political and architectural issue at the end of the war. After its final collapse in 1765 , the prince administrator decided that the whole building must have been rebuilt in a "Classic" style (Klassizismus) and entrusted the task to the architect Friedrich August Krubsacius. The prince was therefore aware of the architectural innovations that have occurred in France with the return of the architect Jacques-Germain Soufflot from Italy, as well as the publications on Greek and Ancient Roman art by Johann-Joachim Winckelmann. In 1769, far from politics, he decided to leave the regency, which was for him then a "very unpleasant and difficult position (une galère bien désagréable)". While traveling in Italy, he has decided to come and settle, in 1770, in France where he later bought the castle of Chaumot (Yonne, France) in 1771 , then in 1775 , the one of Pont-surSeine (Aube, France) was considered to be one of the most beautiful castles in Champagne ("Fig. 3")

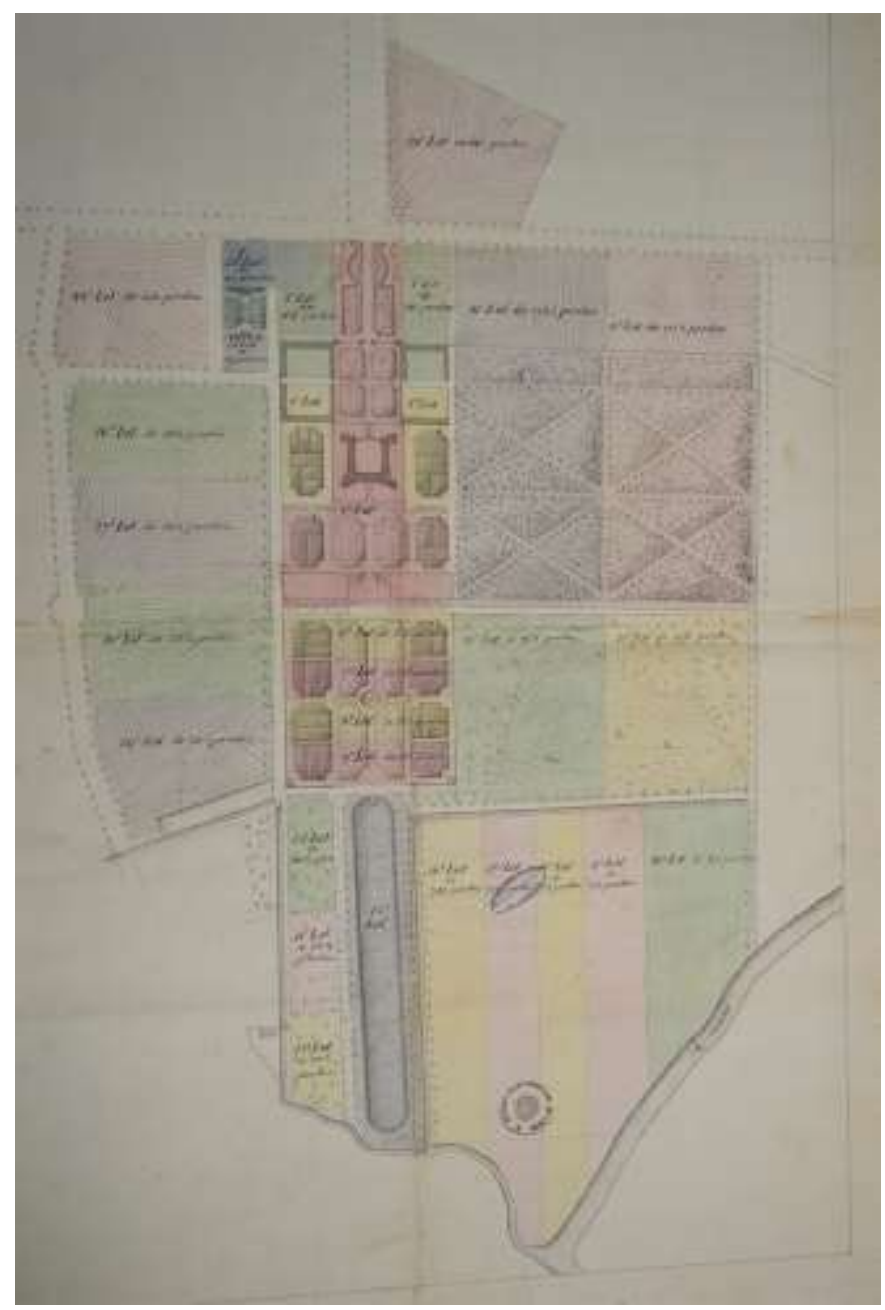

Fig. 3. The Map of Pont-sur-Seine, engavring, 1798@ Arch. dép. de l'Aube. 
The prince had surely met the architect Giesel in 1764 on the site of the palace of the "Chevalier de Saxe" with whom he had implemented an army reform planned since the defeat of Pirna in 1756. By putting himself at the service of the prince, the architect, not without interest, has found a place near a cultivated prince of one of the great European families. As an accomplished artist, he held the position of the designer in the Prince's House. He also operated as a music and drawing master for the prince's children. Upon his arrival, he has been responsible for drawing the plans for the castle of Le Vaudreuil (France, Eure) that the prince had plans to acquire. He also made temporary decorations in the garden of Chaumot for Chiara Spinucci, the prince Xavier's wife.

It is especially the various construction sites at Pontsur-Seine, which bring out the talents of the architect. The prince instructed his architect to manage his garden with the help of managers, gardeners, and workers. On the practical side, the gardens depended on Antoine Speiser, botanical gardener, and the gardener Sieur d'Amours. The architect modified the terraces and performed the construction of the grand staircase, which was mentioned in 1788 in his biography. The map of Trudaine's atlas shows its state before the works. In 1776, the prince asked that several terraces be made in the form of glazes planted with lawn. There is only one terrace known by the drawings made for repair works after various collapses of 1778 and 1780.

To know the state of the garden after the architect's work, there is a description of the parts of the garden in 1787 and a plan of the estate in 1798. The garden consisted of two axes ("Fig. 3"): the north-south axis consisting of the castle, the terraces, and the pond; the east-west axis consisting of the small park and meadows. The area was bounded to the north by the Seine and to the south by the main royal road and enclosed by walls. On the other side of the road was the avenue towards the forest, also called the "large par". It led to the half-moon in front of the castle, and to its left, the kennel and the melon were placed along the road. A forecourt separated the two sets of commons with a lawned space. The castle, surrounded by ditches, opened onto a first terrace. A second terrace was located opposite the castle in the direction of the Seine. A staircase led down to the third walled terrace, which ended with a small bridge. In the axis of the castle and the staircase, there was a space with a large pond in it. To the east of it, there was a vegetable patch, and to the west, the mill was placed along a small canal. On both sides of the pond, several rows of trees were planted.

On the right side of the castle was the "small park" bounded by grid and diamond paths. This route generated groves in the form of rectangles (south) and diamonds (north). This area was separated from the rest of the garden by two large tree-covered paths called a "mail". A large meadow served as a warren below. A plan from 1799, known from a copy of the XX century, makes it possible to imagine winding alleys in an "English-style" grove. In another grove, there was a cooler with a "room" used for parties. The "Chambellan's grove", consisted of rectilinear paths leading to spaces where the garden benches were, as well as lawns used for a game of "trou-madame" or even a "tape-cul" swung between two sculptures of vases on stone pedestals.

The prince did not seem to give in more to the fashion of picturesque gardens since he has mainly set up flower beds, a melon tree, and orchards to provide his table. In the latter, he planted peaches, cherry trees, plum trees, and pear trees. In the vegetable patch, there were carrots, turnips, black radishes, horseradish, spring onions, and leeks. Gardeners added more onions, green beans, cucumbers, cabbage, shallots, garlic, spring onions, leeks, parsley, carrots, artichokes, and melons. The garden was completed by vineyards, then made up of ornamental and alignment plants. The prince has new alleys made of hornbeams, white mulberry trees, or even the alleys of the mall where he had poplars, planted. For his flowerbeds, he has roses and lilacs put on.

The castle's garden was, therefore, geometric with beautiful alleys and avenues for games and festivities where plants and trees were as much for pleasure as for their agricultural and culinary utility.

In the spring of 1781 , the prince decided to have a "large staircase from the terrace of the flowerbeds to the vegetable garden in his castle of Pont" built with a cave and decorated with two sculptures of sphinxes. He shared it with his architect Giesel and master mason Pierron, "rue des Escouffes" in Paris. The prince asked his architect to propose a drawing ("Fig. 4"). 


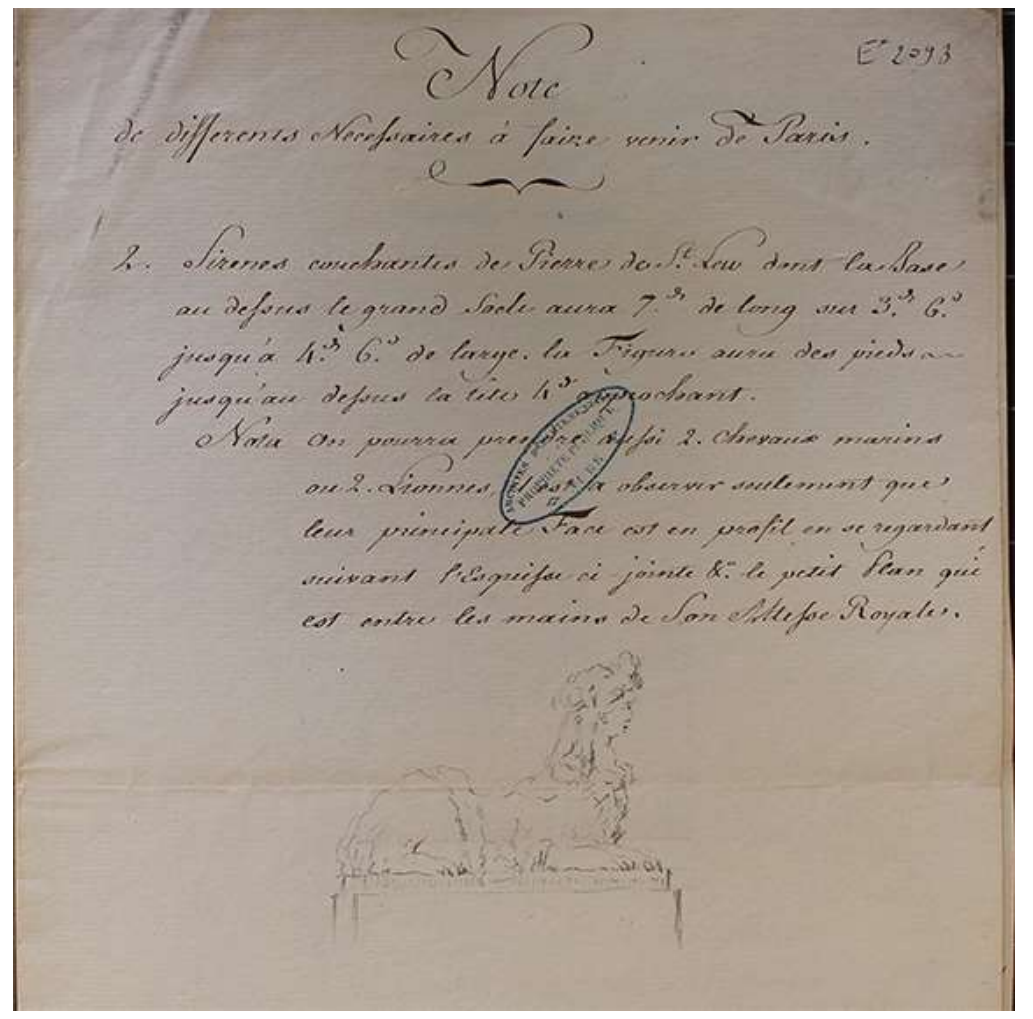

Fig. 4. The Sphinx project for Pont-sur-Seine castle, Johann August Giesel's drawing, 1781-1782 @ Arch. dép. de l'Aube.

The horseshoe staircase consisted of two flights of steps and stone balusters. It was a sandstone staircase with a decoration of "brick paintings," as shown in the drawing of the reconstruction of the terrace in 1780 . The decoration of the staircase was completed by "two gargoyles in sandstone at both ends [...] to throw the water by two spears". To complete the staircase, the architect offered him a model of a lion or "mermaids from St Leu stone" or "two sea horses or two lionesses". This representation is very close to the sphinx sculptures of the castle of Marly that the prince visited in 1769. There are similar models in Saxony in the garden of Pillnitz, a castle that the prince particularly appreciated ("Fig. 5").

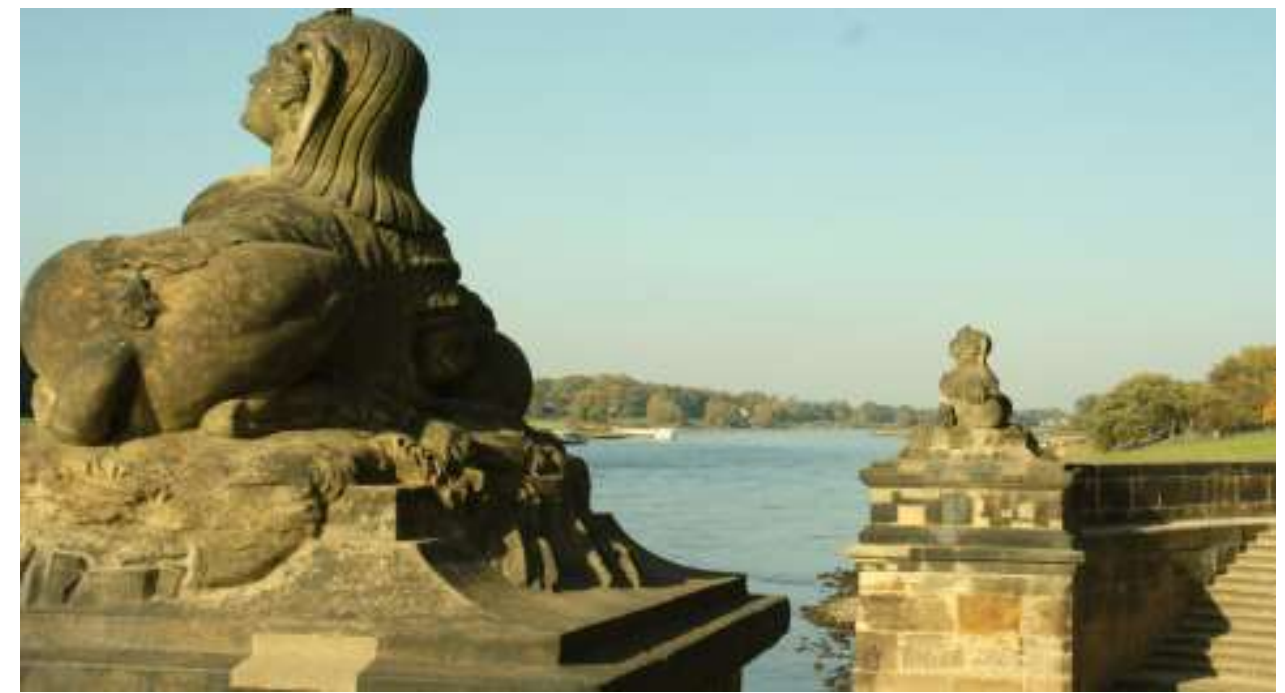

Fig. 5. Sphinx Pillnitz castle, photography $\odot$ Wikipedia. 
Mason Pierron sent his models arriving on May 8, 1781: the prince "found that they would have been better if the head of the lioness has been turned a little as if it seemed to be watching the people who come to climb the stairs and the whole body and the head would have been a little higher "closer to the Pillnitz sculptures. He added that "these two lionesses would have no water to throw". This means that the sculpture would have its mouth closed, and no plumbing work would have been required. On May 22, 1781, he ordered its execution. The sculpture must have been in the "Saint-Leu" stone and cost "900 pounds both together". He added that they must have been in one piece. The staircase work ended in July 1782 with the installation of the last balusters. The sculptures, which consisted of two parts, remained in place until 1798, the date on which they have been moved to the chief town of the department and perhaps, thereafter, transported to Paris.

The construction ended with the cave, which form is poorly known. It was located below the two flights of stairs and in its center has had an oval basin. The architect Giesel wrote that he wanted to vault the cave with stone from the village of Resson (Aube). The walls of the cave have been therefore made of a very light white stone sealed with whitewash. In conclusion, we can see that Giesel worked mainly at Pont-sur-Seine, but the garden's castle was mostly in a classical style with no follies constructions. We can search how and from whom he knew about follies and "English-style" gardens

\section{INSPIRATION FOR THE ARCHITECT'S ART OF GARDENS}

According to his biographer, when he arrived in France in 1773, Johann August Giesel met in Paris Jean-François-Thérèse Chalgrin (1739 - 1811), the architect of the Count of Provence (future King Louis XVIII). The biographer Johann Gottlob August Kläbe wrote about it: "This stay in Paris was used by $\mathrm{Mr}$. Giesel to continue his studies, where he received under the protection of the prince, the best works, and learned, thanks to M. M. Chalgrin and Legrand, the best taste".

For a long time, the architect Legrand at the service of Prince Xavier was confused by historians with Jacques-Guillaume Legrand (1753 - 1807), the architect of the wheat hall in Paris, but it is, in fact, PierreGermain Legrand - the architect of the duke of Orleans. For the latter, he redeveloped the "Félicité" grove, with the pavilion, the waterfall, and the labyrinth in SaintCloud palace (Haut-de-Seine, France). In 1785, he was the chief architect of the Duke of Orleans and received 2,000 French pounds of wages. Legrand was in charge of the first works in Pont-sur-Seine. But very criticized for his drawing skills, the prince decided not to call on him anymore from 1776.
Jean-François-Thérèse Chalgrin has been a renowned architect since his work in 1767 for the "Hôtel de Saint-Florentin" in Paris based on a drawing by the architect of King Ange-Jacques Gabriel. He was also noticed by the realization, in 1770 for the count of Mercy-Argenteau, of the "Party Room" at the Luxembourg Palace during the marriage of the Dauphin with the Archduchess Marie-Antoinette of Austria. Subsequently, the architect carried out several constructions, including plans for gardens that are still little known. In 1777, he gave the drawings for a temple of love at a property in Fresnes-sur-Escaut (North, France). Then in 1785, he gave the plans for a picturesque garden in Versailles, the property of the Countess of Balbi, mistress of the Count of Provence.

The architect Giesel was thus able to know the achievements of the architect of the Count of Provence thanks to his relationships: he was a friend with a certain Gaetner with whom he spent two stays in Versailles in 1780. Was young Giesel able to take advantage of Chalgrin's relationships and enter the sphere of the Count of Provence? Nothing is certain since the letters with Prince Xavier say nothing about it. The works in the Pont garden are the only works known to the Saxon architect in France, but as we have seen, there are very few traces of the creation of a picturesque garden. He also got to know the trendy gardens through various publications and visits. The first could be the engravings of Georges-Louis Lerouge produced from 1775, which reflect different French, English, and German gardens in the "Anglo-Chinese" taste.

He could also see gardens and constructions made between 1773 and 1782 . The ruin of the palace der Sekundogenitur is a structure of which one would only see the upper part as the entrance portal of the hotel de Tellusson realized in 1778 by the architect Claude Nicolas Ledoux. It is treated as an ancient half-buried triumphal arch. We can still think of the ruins of the Naumarchy in the Parc de Monceau ("Fig. 6"). The follies were carried out between 1773 and 1779 for the Duke of Chartres, son of the Duke of Orleans. The architect Giesel was able to visit this place with Legrand, who worked with the Duke of Orleans. 


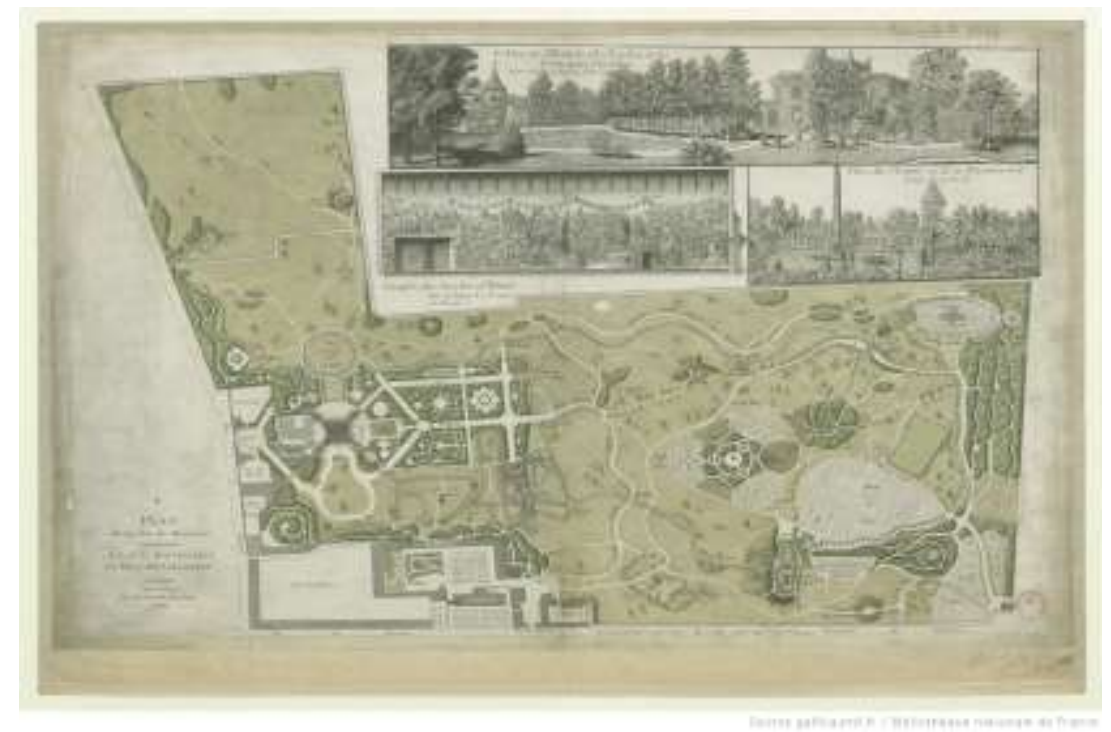

Fig. 6. The Map of Monceau park, engraving, 1783@ Gallica.

\section{CONCLUSION}

Johann August Giesel is absolutely a man of art and culture. He could draw perfectly and write French and German. He knew mathematics, geometry, and planning. He was knowledgeable enough in music to teach it to the children of a princely couple who became good musicians. This study tried to demonstrate that by working on the Pont-sur-Seine domain in France, the architect knew the rustic economy and the management of a vast agricultural domain. He was thus able to perfect his knowledge of military and domestic architecture in a more technical way. Inspired by many Parisian creations, including the garden of Monceau, he also knew the small constructions of fashionable or "Anglo-Chinese" gardens. When he returned to Dresden in 1782, he became a specialist in garden architecture, the ruin built in the palace der Sekundogenitur is only a small piece of a career which should be studied further.

\section{References}

[1] H. Keller, Nachrichten von allen in Dresden lebenden Künstler, Leipzig, Verlag der Dysischen Buchhandlung, 1788. [News from all artists living in Dresden, Leipzig, Dyk, 1788]

[2] J. G. Meusel, Teutsches Künstlerlexikon, Lemgo, Meyersche Buchhandlung, 1789, 2 vol. [German artist lexicon, Lemgo, Meyer, 1789 ]

[3] J. G. A. Kläbe, Neuestes gelehrtes Dresden, Leipzig, Voss und Comp, 1796. [Latest scholarly Dresden, Leipzig, Voss, 1796]

[4] F. Löffler, "Giesel, Johann August", in: Neue Deutsche Biographie 6 (1964), p. 385 [online]. ["Giesel, Johann August", in: New German biography 6 (1964), p. 385]
[5] F. Löffler, Das alte Dresden. Geschichte seiner Bauten u.a., Leipzig, Seemann, 2006. [Das alte Dresden. Geschichte seiner Bauten, Leipzig, Seemann, 2006.

[6] B. Bechter, "Vom rechenbergischen Garten zum Blüherpark. Die wechselvolle Geschichte einer Dresdner Gartenanlage", in: Die Gartenkunst, $\mathrm{n}^{\circ}$ 17, 2009, pp. 112-145. ["From the computing garden to the blooming park. The eventful history of a Dresden garden", the Garden art, ${ }^{\circ} 17,2009$, pp.112-145]

[7] Ph. Meyzie, "François-Xavier de Saxe dans son château de Pont-sur-Seine. La table d'un prince européen du XVIIIe siècle", in: Châteaux, cuisines \& dépendances, Bordeaux et Paris, Ausonius, 2014, pp.251-260. ["François-Xavier de Saxe in his castle of Pont-sur-Seine. The table of an 18th century European prince", in: Castles, kitchens \& outbuildings, Bordeaux and Paris, Ausonius, 2014, pp.251-260]

[8] C. Sciama, "Jean-François-Thérèse Chalgrin et le Comte de Provence (1771-1791)", in: Chalgrin et son temps, architectes et architecture de l'Ancien Régime à la Révolution, Bordeaux/Paris, William Blake \& Co/Art et Arts : Belles Lettres, 2016, pp. 21 - 30.["Jean-François-Thérèse Chalgrin and the Count of Provence (1771-1791) ", in: Chalgrin and his time, architects and architecture from the Old Regime to the Revolution, Bordeaux / Paris, William Blake \& Co / Art and Arts: Belles Lettres, 2016, pp. 21 - 30]

[9] V Champier, Palais Royal, Du Cardinal de Richelieu à la révolution, Paris, Société de Propagation des Livres d'Art, 1900, 2 vol. [Palais Royal, From Cardinal Richelieu to the Revolution, Paris, Société de Propagation des Livres d'Art, 1900, 2 vol.]

[10] C. de Bourgoing (dir.), Jardins romantiques français (17701840), Du jardin des Lumières au parc romantique, Editions Paris Musée, 2011. [French Romantic Gardens (1770-1840), From the Garden of Lights to the Romantic Park, Editions Paris Musée, 2011] 